\title{
Madrid Hospitals and Welfare in the Context of the Hapsburg Empire
}

\author{
TERESA HUGUET-TERMES
}

\begin{abstract}
Introduction
Over the last twenty-five years, the tendency of historians to see extreme distinctions between Catholic and Protestant health care provision has faded away, mainly thanks to the works of Brian Pullan on Venice and Jean-Pierre Gutton on Lyons. It has become generally accepted that Catholic areas pursued efficient and highly selective welfare policies, especially as regards the control of public begging, in order to achieve long-term social improvement by giving the poor both an education and opportunities to work. ${ }^{1}$ In order to centralize and co-ordinate the resources available, welfare services were improved by the creation of institutions under the auspices of the Church and lay authorities. ${ }^{2}$ Public begging was prohibited, and relief was limited to deserving local inhabitants and restricted to the period before they could be set to work, while the itinerant poor were given only the temporary assistance they required. It has also been generally assumed that Madrid was included among the towns where a programme of reform led by lay elites following the guidelines of the poor law tract De subventione pauperum (On Assistance to the Poor) by Juan Luis Vives (1526) prevailed from the second to the fourth decades of the sixteenth century. In accordance with this programme, hospitals for beggars and other "undeserving" poor were founded, supposedly reaching a peak in the seventeenth century. In the confines of such institutions, unworthy individuals could be punished if they resisted the obligation to work. ${ }^{3}$
\end{abstract}

I am grateful to the Dirección General de Investigación of the Comunidad de Madrid for having funded my research project on Hospital Care in Hapsburg Madrid between 2000 and 2003; to Philip Banks for his help in correcting the English style of an earlier working version of this paper, and to Caroline Tonson-Rye for her amendments and suggestions in its final edition. Last but not least, my thanks go to Jim Amelang and M. José del Río for inviting me to the seminar of Cultural History at the Autonomous University of Madrid where I was able to discuss many of these results and also to Cristina Álvarez-Millán and Francesca Español for their suggestions and for providing sources.

\footnotetext{
${ }^{1}$ Brian Pullan, Rich and poor in Renaissance Venice: the social institutions of a Catholic State, to 1620, Oxford and Cambridge, MA, Harvard University Press, 1971; Jean-Pierre Gutton, La société et les pauvres: l' exemple de la généralité de Lyon, 1534-1789, Paris, PUF, 1971.

${ }^{2}$ For recent general surveys on the question, see Guenter B Risse, Mending bodies, saving souls: a history of hospitals, Oxford, Oxford University Press, 1999, pp. 216-19; Mary Lindemann, Medicine and society in early modern Europe, Cambridge, Cambridge University Press, 1999, pp. 120-54; John Henderson, The Renaissance hospital: healing the body and healing the soul, New Haven and London, Yale University Press, 2006.

${ }^{3}$ See, for instance, Colin Jones, 'Perspectives on poor relief, health care and the Counter-Reformation in France', in Ole Peter Grell, Andrew Cunningham, Jon Arrizabalaga (eds), Health care and poor relief in CounterReformation Europe, London and New York, Routledge, 1999, pp. 215-39, on p. 218; Robert Jütte, Poverty and deviance in early modern Europe, Cambridge, Cambridge University Press, 1994.
} 


\section{Madrid Hospitals and Welfare}

However, measures for poor relief have primarily been studied in cities with a strong communal tradition and a sophisticated system of urban government. It is these studies, simplistically extrapolated to less well-researched cities like Madrid, that have provided the basis for the picture of the principal characteristics of the Catholic system of welfare. ${ }^{4}$ But what was the true situation in a villa-Madrid — which was essentially a creation of the early modern period, and which was designed by the Hapsburg dynasty to be the centre of government of the largest Catholic empire history has ever known? It is clear that both the history and character of Madrid (a small town that had become the capital and the home of the royal court in 1561) are very different from those of the republics, principalities and cities of Spain, Italy and France. The latter were endowed with municipal dynamism, strong manufacturing, trade and guild traditions, and possessed systems of relief that have attracted the attention of historians and have generally been regarded as pioneering.

The aim of this paper is to summarize current research on poor relief in Madrid, including the policy towards the sick, between 1561 and 1700. After briefly reviewing the current state of research, two particular features will be focused on, the assistance given to the sick poor, and that which all other categories of poor people received. It will be argued that, in contrast with other Catholic areas, improvements in health care rather than the redemption and rehabilitation of beggars and vagrants were seen as a useful ideological and political resource for the dynasty up to 1700 .

In order to illustrate these two topics, three episodes will be examined. First is the plan for poor relief exemplified by the ordinances of the General Hospital of Madrid (1589). In theory, the hospital was the result of the unification of various existing institutions, a move undertaken only five years after Madrid had been declared the capital. Second, through sources such as visitation and account books, the history of this institution will then be traced from 1613 to 1677 , reflecting how policies were carried out in practice. Finally, brief reference will also be made to the new project in 1673 for a shelter for beggars and the reasons for its "renewed" failure.

\section{A Historiographical Balance Sheet}

The panorama provided by Jon Arrizabalaga on health care and poor relief in CounterReformation Castile brings to light the surprising fact that no comprehensive study of poor relief and medicine in Madrid has ever been undertaken. ${ }^{5}$ Remarkably and unfortunately, we are still at a historiographical stage in which this aspect of the city's history is depicted in somewhat simplistic and black and white terms. The reasons for this lie in the dispersion of documents as a result of the upheaval of the Civil War and in the easy acceptance of

\footnotetext{
${ }^{4}$ References to studies on Venice and Lyons have been already made in note 1 . The following interesting studies have been carried out on Florence, Seville and Valencia: Katharine Park, 'Healing the poor: hospitals and medical assistance in Renaissance Florence', in Jonathan Barry and Colin Jones (eds), Medicine and charity before the welfare state, London, Routledge, 1991, pp. 26-45; John Henderson, 'Healing the body and saving the soul: hospitals in Renaissance Florence', Renaissance Studies, 2001, 15 (2): 188-216; Carmen López Alonso, Locura y sociedad en Sevilla: Historia del Hospital de los Inocentes (1436?-1840), Seville, Diputación Provincial, 1988; María Luz López Terrada, 'Health care and poor relief in the crown of Aragon', in Grell, Cunningham and Arrizabalaga (eds), op. cit., note 3 above, pp. 177-200.

${ }^{5}$ Jon Arrizabalaga, 'Poor relief in Counter-Reformation Castile: an overview', in Grell, Cunningham and Arrizabalaga (eds), op. cit., note 3 above, pp. 151-76.
} 


\section{Teresa Huguet-Termes}

the "Whiggish" approach to the subject by physicians interested in history, who to a great extent relied on the information provided by nineteenth-century chroniclers of the "greatness" of their city's past, and consequently produced contributions of very limited and sometimes even suspect value. ${ }^{6}$

To the best of my knowledge, the most original contributions to this subject are the few references to poor relief in Hapsburg Madrid in Linda Martz's magnificent study of Toledo, and the more recent studies by José Luis de los Reyes and Miguel Ángel García on social control. ${ }^{7}$ Although excellent research has been undertaken on the history of Madrid confraternities, little has been published on mutual assistance within the confraternities themselves, or on the care they offered to members of the public. ${ }^{8}$ In this respect, the work of William J Callahan on the very exceptional confraternity of "Refugio", which looked after people who were not members of their brotherhood, has not yet been surpassed. ${ }^{9}$ Among recent studies of Madrid's hospitals for foreigners, that by Concepción

\footnotetext{
${ }^{6}$ See José Alvarez Sierra, Los hospitales de Madrid de ayer y de hoy, Madrid, Artes Gráficas Municipales, 1952; idem, Antón Martín y el Madrid de los Austrias. La primera escuela de ayudantes técnicos sanitarios del mundo, San Baudilio de Llobregat, Imprenta de los Hermanos de San Juan de Dios, 1961; José Aparicio Simón, Historia del Real Colegio de San Carlos de Madrid, Madrid, Aguilar, 1956; Gregorio Marañón, 'El pasado, el presente y el porvenir del Hospital General de Madrid', in Gregorio Marañón, Obras Completas, Madrid, Espasa Calpe, 1967, vol. 4, pp. 287-99; Ricardo Valladares Roldán, Hospital Provincial de Madrid, Madrid, Diputación Provincial de Madrid, 1979; J de la Villa, Historia del Hospital General, Madrid, Aguilar, 1956. A recent useful survey for Castile is: José García Oro and María José Portela Silva, 'Felipe II y el problema hospitalario: reforma y patronato', Cuadernos de Historia Moderna, 2000, 25: 87-124; and for Madrid: José Luis de los Reyes Leoz, 'Aproximación a las fuentes documentales para la historia de la beneficencia madrileña en la Edad Moderna: los hospitales de Madrid', in Primeras jornadas sobre fuentes documentales para la historia de Madrid, Madrid, Comunidad de Madrid, 1990, pp. 253-64.

${ }^{7}$ Linda Martz, Poverty and welfare in Habsburg Spain: the example of Toledo, Cambridge, Cambridge University Press, 1983; José Luis de los Reyes Leoz, 'Madrid, laboratorio de pobres: asistencia y control social en la Corte de los Austrias', unpublished PhD dissertation, Universidad Autónoma de Madrid, 2000; Miguel Ángel García Sánchez, 'Mujeres pobres y sociabilidad en el Madrid moderno. El Hospital de la Pasión, 1565-1700', Torre de los Lujanes. Revista de la Real Sociedad Económica Matritense, 2004, 52: 203-32. Pedro García Barreno has edited a manuscript of the ordinances of the General Hospital of Madrid (1589) and published a few documents on the amalgamation of Madrid's hospitals that were found in the Archivo Histórico Nacional de Protocolos. See Pedro García Barreno, 'El Hospital General de Madrid. Su primer Reglamento (1589). Parte 1', Arbor, 1996, 153 (603): 55-112. On the Hospital of Antón Martín, see Luis Ortega Lázaro, 'Antón Martín: el hermano Antón Martín y su hospital en la calle Atocha de Madrid, 1500-1936', Boletín Informativo Hermanos Hospitalarios, 1981,73: 3-43. On the Hospital of la Latina, see Mercedes Agulló Cobo, 'El hospital y convento de la Concepción de Ntra. Señora (La Latina)', Villa de Madrid, 1976, 50-53: 26-34, and Javier Tomé Bona, 'El Hospital de la Concepción Francisca, vulgo La Latina', Anales del Instituto de Estudios Madrileños, 1989, 27: 307-316. The study by Juan Manuel Núñez Olarte, El Hospital General de Madrid en el siglo XVIII, Madrid, CSIC, 1999, provides very little information on the earlier centuries of the history of that institution. For the early modern period, see Teresa HuguetTermes, 'La mayor grandeza de la monarquía y el mayor blasón de Madrid: algunas reflexiones en torno a los opúsculos de Gregorio de Aldana sobre los Reales Hospitales (1661) y (1666)', in José Martínez Pérez, et al. (eds), La medicina ante el nuevo milenio: una perspectiva histórica, Cuenca, Ediciones de la Universidad de Castilla-La Mancha, 2004, pp. 271-86; idem, 'Carità e sanità per una nuova capitale: Madrid asburgica (1561-1700)', Medicina e Storia, 2003, 3 (6): 93-113; idem, 'Iglesia, socorro de pobres y asistencia hospitalaria en el Madrid de los Austrias (1561-1700): algunas reflexiones', in Laurinda Abreu (ed.), Igreja, Caridade e assistência na Peninsula Ibérica (sécs. XVI-XVII), Lisbon, Colibri-CIDEHUS-UE, 2004, pp. 47-66.

${ }^{8}$ Elena Sánchez de Madariaga, Cofradias y sociabilidad en el Madrid del Antiguo Régimen, PhD Dissertation, Universidad Autónoma de Madrid, 1996 (Microfiche, 1997); José Luis de los Reyes Leoz, 'La Cofradía de la Soledad: religiosidad y beneficencia en Madrid (1567-1651)', Hispania Sacra, 1987, 39: 147-84; idem, 'Beneficencia y sociedad: La Inclusa de Madrid (1567-1651)', unpublished dissertation, Universidad Autónoma de Madrid, 1987.

${ }^{9}$ William J Callahan, La Santa y Real Hermandad del Refugio y Piedad de Madrid, 1618-1832, Madrid, Instituto de Estudios Madrileños-CSIC, 1980.
} 


\section{Madrid Hospitals and Welfare}

Lopezosa deserves mention, ${ }^{10}$ and Florentina Vidal's history of the Hospital de San Andrés de los Flamencos, founded in 1620 to provide relief for Flemish visitors to the Spanish court, is also useful. ${ }^{11}$ Nevertheless, Vidal places excessive emphasis on the idea that, in Golden Age Spain, poverty was not understood in economic terms but as part of God's plan. The rich could attain eternal salvation through charitable works. For this reason many hospitals and infirmaries were built which gave shelter to the healthy and cared for the sick, but most of all saved the souls of both. ${ }^{12}$ Such an interpretation is partly true, but is by no means the whole story in Madrid. The increase in available archive information has not yet led to a reappraisal of the conclusions of this approach.

\section{Madrid and Health Facilities: from City to Court}

According to Gonzalo Fernández de Oviedo, in 1513 Madrid had 3,000 inhabitants. Three years later, the emperor Charles V arrived in his new kingdom, but it was not until 1561 that his son and heir, Philip II, chose Madrid as the main capital of his empire. The reasons for this choice are still obscure, but everything seems to indicate that Madrid was selected because it lay in the geographical centre of the kingdom. Imbued by humanist influences concerning the place and training of kings and princes, Philip decided it was possible to create there a cultural world of exquisite perfection; a prosperous city that provided a wide range of goods and crafts as well as being a centre for music, letters and painting. Yet, the things of this world were not supreme. The closeness of El Escorial reminded madrileños of the eternal rest of the world to come.

By 1563 , the population had increased to 30,000 inhabitants. A year later, a report (memorial) was written at the request of the king, giving directions for a major reform of the city. This included plans for the construction of many buildings, which would provide the fledgling capital with a new prison, a main square and a city hall, as well as a new General Hospital, but for several reasons, the plan was not undertaken until twenty years later. The population continued to increase and by the end of the century Madrid had grown to 90,000 inhabitants distributed over thirteen parishes. The dark side of this development was the overwhelmingly poor conditions of hygiene and high levels of poverty and illness. ${ }^{13}$

It is within this context, without forgetting the general environment produced by the Counter-Reformation, that some of the reasons for hospital reformation should be considered. María José del Río's recent study of royal ceremonies in the streets and squares of the city casts considerable light on it as a stage for projecting the monarchy's grandeur. Urban planning in this period makes it difficult to imagine Madrid as offering a suitably impressive backdrop for its role as the capital. Yet, it was able to provide a sufficiently appropriate setting for the sovereign power. Public ritual converted the city as a whole into

\footnotetext{
${ }^{10}$ Concepción Lopezosa Aparicio, 'La asistencia hospitalaria en Madrid en la Edad Moderna. Hospitales regionales y extranjeros', Madrid. Revista de Arte, Geografía e Historia, 2002, 5: 119-40.

${ }^{11}$ Florentina Vidal Galache, Fundación Carlos de Amberes: historia del Hospital de San Andrés de los Flamencos, 1594-1994, Madrid, Nerea, 1996.

${ }^{12}$ Ibid., pp. 26, 38.

${ }^{13}$ Jacques Soubeyroux, 'Pauperismo y relaciones sociales en el Madrid del siglo XVIII (I)', Estudios de Historia Social, 1980, 12-13: 7-228.
} 


\section{Teresa Huguet-Termes}

a symbolic expression of this power since it was displayed to the world as the head and the embodiment of the values of what was known as the Catholic monarchy. ${ }^{14}$

Earlier movements had led to the founding of several institutions for the relief of the sick and needy. The environment of exalted religious fervour found in Spain at the end of the fifteenth century and the feeling that life was brief-strongly influenced by the terrible epidemics which affected the population-inspired saintly ideals of service to the poor. Redemption through the renunciation of worldly goods at death in order to benefit the needy seems to have become a priority for the wealthy. Such wills and donations responded to the Christian tradition that accepted poverty as a natural part of life. There was an obligation on the powerful to contribute to the relief of the poor and, in turn, the donors themselves would be rewarded with eternal salvation. One of the traditional ways of fulfilling this duty was for a rich donor to pay for a large number of masses to be said in the hospital church for his or her soul. Nevertheless, it should be borne in mind that other personal and political motives might also lie behind such initiatives. ${ }^{15}$

When Charles V arrived in Spain in 1516, he gave about eleven million maravedis to pious institutions in the diocese of Toledo (which included Madrid) "as long as they exercise continual care of the poor". ${ }^{16}$ Eleven medical institutions were included among the forty-one religious establishments in Madrid. These were the Hospital de San Lázaro for lepers; the Hospital del Campo del Rey (founded before 1421) which contained twelve beds for women; the Hospital de San Ginés de los Caballeros (for worthy paupers); the Hospital de la Paz (for the incurably sick); a place of seclusion for devout women (1448); the plague house, the Hospital de San Antón (1438); the Hospital de Santa Catalina de los Donados (1467), which provided relief to honest elderly artisans and was supervised by the Church; and a hospital for pilgrims. The Hospital de Beatriz Galindo (1500) organized relief for twelve lay sick people and for six priests or other people "of quality" in a separate room. There was also a shelter for children, the Albergue de San Ildefonso de los Niños de la Doctrina (1478), which depended on the council of the villa. ${ }^{17}$ Thus even before Madrid became the capital, relief was provided to sick paupers and to other categories of the respectable poor, although not to wandering beggars. Yet, with a

\footnotetext{
${ }^{14}$ María José del Río Barredo, Madrid Urbs Regia. La capital ceremonial de la monarquía católica, Madrid, Marcial Pons, 2000, p. 15.

${ }^{15}$ For an interesting insight into the religious experiences of Spanish Catholics between the fourteenth and the seventeenth centuries regarding charity and health care, albeit focusing on the town of Zamora, see Maureen Flynn, Sacred charity: confraternities and social welfare in Spain, 1400-1700, London, Macmillan, 1989. An example of how other kinds of interests may have shaped hospital administration and life has been magnificently investigated by Sandra Cavallo, Charity and power in early modern Italy: benefactors and their motives in Turin, 1541-1789, Cambridge, Cambridge University Press, 1995. Madrid itself was an example of this kind of situation. The Hospital de la Latina and the Hospital de la Corte were soon to be taken as an example of conflicts. See HuguetTermes, all references, op. cit., note 7 above.

${ }^{16}$ Ramón Carande, Carlos V y sus banqueros: la vida económica en Castilla (1516-1556), 3 vols, Madrid, Sociedad de Estudios y Publicaciones, 1944-65, vol. 2, p. 470.

${ }^{17}$ Gil González Dávila, Teatro de las grandezas de la Villa de Madrid, Corte de los Reyes Católicos de España, Madrid, Thomas Iunti, 1623 (facsimile edition: Madrid, 1986), pp. 300-7; Eulogio Varela Hervías (ed.), Historia de la antigüedad, nobleza y grandeza de la Villa de Madrid, escrita por Jerónimo de Quintana, Madrid, Ayuntamiento de Madrid, 1954, pp. 227-31, 994-1016; Pedro Escolano de Arrieta, Práctica del Consejo Real, Madrid, en la imprenta de la viuda e hijo de Marín, 1796, ch. 71, p. 613; Archivo Regional de la Comunidad de Madrid (hereafter ARCM), Fondo Hospitales, leg. 5302/1, fol. 1r.
} 


\section{Madrid Hospitals and Welfare}

population of 25,000 inhabitants in 1546, the capacity of the hospitals in Madrid was extremely limited from both a quantitative and a qualitative point of view.

On 1 March 1535, the Royal Council sent a request to the council of the villa of Madrid for the following information: the number of hospitals in Madrid; the names of their founders and when they had been founded; their income and amount of alms collected; their expenses; and, "most important" of all, which of them would be appropriate to convert into a new General Hospital, as stipulated by the Cortes of Segovia in 1532. In addition, the Royal Council wished to know how many hospitals should be left in the city and which of them required no reform, so that they could be easily incorporated into the General Hospital. Finally, it asked "if the process would be detrimental to anybody and if so, who that person was". The circumstances prompting the request are included in the document:

... the fact that there are in the cities and villas too many hospitals with the resulting inconvenience that the poor and sick are not treated and cared for as they deserve and so, in accordance with the desire of the patrons, we will order that there should be in every town only one general hospital into which all the others should be consolidated and in the main towns there should be two hospitals, one for contagious diseases and one for non-contagious ones. ${ }^{18}$

These initial steps in Madrid reflected a new perception of the endemic poverty that had become increasingly noticeable in social terms since the 1520s. In Castile, repression of vagrancy had been customary at least from the mid-fourteenth century. Nevertheless, the laws were largely ineffective. Philip II promulgated a new poor law for Castile in 1565. But the references to the prohibition of begging and to the confinement of beggars within closed institutions which had appeared in the law of 1540 were suppressed. As Jon Arrizabalaga has stated:

In the complex economical, social and cultural transition from feudalism to capitalism, a new perception of the poor as a social problem and a threat to public order and health was promoted in the urban areas, where poverty manifested itself most dramatically, in contrast with a perception, more traditional in medieval Christendom, of the poor as individuals who were materially and spiritually complementary to the rich and therefore helped to make up the balance of the whole social structure. ${ }^{19}$

Consequently, from 1520, a growing number of initiatives were undertaken to restrict begging and discourage vagrancy. Proposals, debates and legislative measures sought by various means to control rather than to eliminate begging. The main feature of the poor law of 1540, promulgated by Charles V and issued by Cardinal Tavera, the Archbishop of Toledo (who was acting as regent in the absence of the emperor), was the establishment of a licensed begging system, according to which only deserving poor natives of, or residents in, any city were allowed to beg. But it failed. Its publication in 1544 gave rise to a controversy that influenced subsequent debates on poor relief in Castile. The Dominican

\footnotetext{
18 “... el hecho de existir en las ciudades y villas demasiados hospitales con el inconveniente resultante que los pobres y enfermos no son curados como merecen, y de acuerdo con los deseos de los patrones, ordenamos que en cada pueblo debe existir sólo un hospital general en el que deben consolidarse todo el resto y en los más importantes, deberá haber dos hospitales, uno para enfermedades contagiosas y otro para las no contagiosas." Archivo de la Villa de Madrid (hereafter AVM), Secretaría, 2-420-11, fol. 3v-4r.

${ }^{19}$ Arrizabalaga, op. cit., note 5 above, p. 155. For an overview of these debates and measures, see Michel Cavillac, 'Introduction', in Cristóbal Pérez de Herrera, Amparo de pobres, Madrid, Espasa Calpe, 1975, pp. IX-CCIV.
} 


\section{Teresa Huguet-Termes}

friar Domingo de Soto, professor of theology at Salamanca, attacked it and defended the freedom to beg of all paupers, without distinction, as established by the Christian religion. He also opposed the confinement of the poor in hospitals, although the poor law only encouraged local authorities to ensure that hospital income and any other funds designated for charitable purposes in cities and towns were actually spent on caring for and feeding the poor. De Soto was in turn fiercely attacked by Juan de Robles, a Benedictine abbot. Influenced by the ideas of Vives, Robles thought that begging-as a social problemshould be regulated. The deserving poor should be provided with relief, while vagrants should only benefit by virtue of work. He considered that poor foreigners should not be excluded from alms and from being cared for, provided they were sick, and that social welfare provisions should be entrusted to the municipal authorities. However, until 1565 at least, nothing was put into practice as regards the law of 1540. In the context of an alarming spread of pauperism over the Hispanic kingdoms, the new royal Pragmática (of 1565) promulgated by Philip II voiced similar concerns to the earlier law in accord with the reforming spirit of the new post-Tridentine times. As a result of this unease, new proposals to control poverty emerged which indicated that each state and city should be in charge of maintaining its poor. When discussing poor relief in early modern Madrid, it is, therefore, essential to differentiate between the periods before and after the establishment of the court in the city, and to evaluate the impact that Philip II's decision to settle there was to have.

\section{The Impact of the Court}

An anonymous Castilian soldier, on leaving Madrid for service in Milan in the opening years of the seventeenth century, considered the city's hospital foundations - in an abstract sense- to deserve a line in a farewell poem: "holy houses where so many sick are treated that such great numbers are strange indeed" (cassas santas do curan tantos enfermos que tanto es cosa extraña) ${ }^{20}$ Several years had elapsed since the splendid procession in 1587 that had transferred Bernardino de Obregón's congregation and its 48 inmates from the houses of Santa Ana to the new general hospital of the villa, at the end of Prado street, ${ }^{21}$ in full view of the many tearful residents of these districts who had come out of their homes to say farewell, bringing to a close the hospital consolidation process, under way since 1566. Before 1561, a more complex situation than that usually found in a basically rural centre can be detected in Madrid. As the amount of research on the city grows, it becomes increasingly evident that this villa enjoyed greater importance in the period than traditionally attributed to it. Although far from attaining the urban and economic development of the main nearby cities (Toledo, Segovia, Valladolid), in the first half of the sixteenth century Madrid was a prosperous town, with jurisdiction over the villages in its hinterland (alfoz), which made it a political and administrative centre and provided it with economic bases, resulting in a population that had grown considerably since the second half of the fifteenth century. Moreover, the itinerant court of successive monarchs and of Charles V

\footnotetext{
${ }^{20}$ Antonio Rodríguez Moñino, La transmisión de la poesía española en los siglos de oro, Barcelona, Ariel, 1976, pp. 296-8.

${ }^{21}$ Francisco de Herrera y Maldonado, Libro de la vida y maravillosas virtudes del siervo de Dios Bernardino de Obregón, Madrid, Imprenta del Reino, 1633, fol. 86v-87r.
} 


\section{Madrid Hospitals and Welfare}

had stayed there on numerous occasions, leaving its impression through the foundation of hospitals and monastic houses. ${ }^{22}$ The existence of a range of "specialized" hospitals reflects the complexity of its urban society. As already noted, by the first half of the century, there were hospitals run by confraternities devoted to the care of lepers, the incurably sick, plague victims, priests, "persons of quality", women, etc. Yet, the process of diversification in Madrid can be even more clearly perceived from the second half of the sixteenth century. Between 1565 and 1600 the number of foundations greatly increased, some sixteen being established in these decades. This period witnessed the origins of some of the trends that were to develop in the seventeenth century, such as the consolidation of concern for the welfare of convalescents, the incurably sick, foundlings, orphan girls, the worthy or deserving poor, foreigners, destitute and repentant women, etc. Among these were to be found some of the most significant welfare institutions of ancien régime Madrid.

In so far as hospital care is concerned, as in the case of other aspects of contemporary society in Madrid, the political, demographic, social and economic consequences arising from the court's presence were great. But so were those of the Counter-Reformation, which occurred at the same time as the city acquired the title of capital of a Catholic monarchy or, according to its champions, "the Catholic monarchy". The establishment of Philip II's court in the villa of Madrid in 1561 conditioned the majority of the developments that took place both in the everyday life of its inhabitants and in its basic socio-economic structures. The distortions arising in economic matters, the problems produced by urban growth, ${ }^{23}$ and those relating to the citizens' religious zeal ${ }^{24}$ are well known. Thanks to the works of Cristóbal Pérez de Herrera and Mateo Alemán, we are aware of serious alterations to the social order resulting from the violent impact of the world of the deprived. The plague epidemics of the closing years of the century and the activities of a professional underclass dedicated to crime and begging, together with widespread poverty, made Madrid the perfect setting for the formulation of a characteristic, clearly urban model of welfare, in which hospitals acquired considerable importance.

The pre-existing hospital structure, dating from the period prior to the court's arrival, soon proved insufficient, and the crown was determined to reform and adapt it to a new city with a growing number of impoverished residents. The institutions of Atocha, San Ginés, San Lázaro, San Ricardo, Santa Ana, Mujeres Perdidas, Campo del Rey, Santa Catalina, Buen Suceso, Amor de Dios, La Latina, and Agonizantes, among others, underwent a dual process of adaptation from 1561 onwards. In the first place, efforts were made (as throughout the kingdom from the 1570s) to reduce the number of small hospitals in order to benefit others that enjoyed a higher income, thereby favouring the existence of the thousandheaded dragon that was to become the new General Hospital of Madrid with its attached houses. Secondly, within the space of a few years, a whole series of hospitals were founded parallel to the latter in an attempt to remedy the deficiencies caused by such consolidation.

\footnotetext{
${ }^{22}$ Virgilio Pinto Crespo and Santos Madrazo Madrazo, Madrid, atlas histórico de la ciudad: siglos IX-XIX, Madrid, Fundación Caja Madrid-Lundwerg, 1995; Cristina Segura, 'Madrid en la edad media. Génesis de una capital (873?-1561)', in Santos Juliá Díaz, David Ringrose and Cristina Segura (eds), Madrid, historia de una capital, Madrid, Alianza, Fundación Caja Madrid, 1995, pp. 13-158.

${ }^{23}$ These problems are studied in Ceferino Caro López, 'Casas y alquileres en el antiguo Madrid', Anales del Instituto de Estudios Madrileños, 1983, 20: 97-153.

${ }^{24}$ Reyes Leoz, op. cit., note 8 above, both references.
} 


\section{Teresa Huguet-Termes}

These were: Expósitos (1572), Arrepentidas (1587), San Roque or General (1587), Buena Dicha (1594), San Antonio Abad (1597), Italianos (1598), San Antonio de los Portugueses (1606), San Andrés de los Flamencos (1606), los Desamparados (1610), San Luis de los Franceses (1615), and Montserrat (1616), to which only a small number of other hospitals were to be added in the course of the seventeenth and eighteenth centuries. Consequently, the general outlines of Madrid's welfare institutions were defined for the period between the first quarter of the seventeenth century and the second half of the eighteenth century.

Before the arrival of the court, the most widespread type of hospital in Madrid was that which, under ecclesiastical patronage, housed a small number of needy persons, just enough to balance the institution's accounts and to "ensure" the salvation of the founder's soul. In the first half of the sixteenth century, hermitages outside the walls were absorbed or appropriated (and some welfare confraternities established in them) by parishes or religious orders. This period thus appears to have been one of major transformation, in which Madrid's growth allowed focal points of religious devotion to be transferred by encouraging the expansion and consolidation of the welfare structure. ${ }^{25}$ One of the most significant appropriations was that of the sanctuary of Atocha run by the Dominicans. On the initiative of the order and with the support of the council of the villa, the beneficiary was a Dominican friary. The hospital confraternity of Nuestra Señora de Atocha was transferred to the hospital of the parish church of San Ginés. Atocha became a centre of devotion where the royal family worshipped, while at the same time the hospital continued to care for and attend to the inhabitants of Madrid and its surroundings. ${ }^{26}$ At a later date, other hospitals disappeared, absorbed by parish churches and religious houses, as was the case of Santa Catalina incorporated into the monastery of San Jerónimo el Real. ${ }^{27}$ The aggressiveness of Madrid's clergy (especially of some religious houses) is indicative of a desire to control land, even on the city's outskirts, and to eliminate alternative centres of devotion, which were points of reference not only for its inhabitants but also for those of neighbouring villages. From the second half of the sixteenth century, what guaranteed continuity for the majority of hospital administrators or brotherhoods may well have been the link, however remote, with an ecclesiastical institution.

There was also a change as regards worship in various welfare institutions. The monastery and parish church of San Martín, which was quick to take on a new charitable function then in fashion, that of burying the destitute who died within the confines of the parish, represents a case in point. The ordinances for San Martín containing a text by the deputy vicario de la villa praising the new institution were immediately approved:

They exercise works of charity with the bodies of the dead, keeping a book of accounts and information concerning their income and expenditure, and by this means a problem that frequently arises in said Parish will disappear; as it is large, when a poor person without the means to pay for his burial dies there, several persons appear, more out of avarice than for charitable reasons, seeking

\footnotetext{
${ }^{25}$ Sánchez de Madariaga, op. cit., note 8 above.

${ }^{26}$ José Luis de los Reyes Leoz, María José del Río Barredo, F Marín Perellón and José Jurado Sánchez, 'Espacio urbano y propaganda política: las ceremonias públicas de la Monarquía y Nuestra Señora de Atocha', in Santos Madrazo Madrazo and Virgilio Pinto Crespo (eds), Madrid en la época moderna: espacio, sociedad y cultura, Madrid, Universidad Autónoma, Casa de Velásquez, 1991, pp. 219-64.

${ }^{27}$ Juan Ramón Romero Fernández-Pacheco, 'Asistencia a los pobres y caridad en Madrid en la segunda mitad del siglo XV', Anales del Instituto de Estudios Madrileños, 1987, 24: 123-31.
} 


\section{Madrid Hospitals and Welfare}

alms to bury the poor individual, and they collect a large amount of money and they keep the greater part, spending whatever they think fit, without rendering accounts to anybody, defrauding the genuine poor of the alms; this they cannot do if there are persons responsible for taking care of this task and work of charity. ${ }^{28}$

The organization of quite a large number of hospitals evolved in a comparable fashion: some were pushed into the background or voluntarily accepted a lesser status, whereas others rose by making themselves increasingly attractive; they pursued their own interests while at the same time collaborating with the Church, which guided or simply followed the initiatives of the faithful. Within this spread of institutions, the Church might advise, but an important role was also played by those who directed the various hospital foundations, or by the laymen interested in creating them and in finding or maintaining a social and devotional space; both groups might also imitate each other. While the confraternity of Santa Catalina exemplified the collective charitable work in Madrid before the arrival of the court, which was to be lost in the course of time, the Hermandad de la Corte showed, as far as the court's hospital was concerned, what was to happen "among the sick poor that it took care of ... soldiers, people whom they took great pity on because of their needs and hardship on seeing them held at court with their orders and dispatches, dying of hunger and without protection and favour, after having defended at risk of life and limb, and the spilling of their own blood, their country, religion and king." 29

The sixteenth-century reforming policies concerning charity and relief for the sick and poor, which were particularly effective in Castile in so far as hospitals were concerned, also affected the confraternities linked to them. The consolidation of hospitals in Madrid between 1566 and 1587 took place with less resistance than elsewhere because of the limited strength of the Madrid confraternities. ${ }^{30}$ Consequently, the objectives of some brotherhoods were adapted within the framework of "renovated" hospitals, a situation which was undoubtedly to influence the welfare functions of their institutions. Some, such as that of Nuestra Señora de Atocha mantained their hospital for some time even though it had theoretically been amalgamated with that of the knights of San Ginés. The Hospital de la Pasión (the women's general hospital) was probably founded by the brotherhood of the Sagrada Pasión de Cristo y Nuestra Señora de las Angustias in 1565, at the instigation of the Madrid alderman, Juan González de Armunia, and a court bailiff, who purchased some houses and installed forty beds. Until 1580 or 1587, it was in a building adjoining the hermitage of San Millán.

\footnotetext{
28 “Ejerciten obras de caridad con los cuerpos muertos teniendo libro, cuenta y razón de lo que llegaren y gastaren y con esto cesará un inconveniente que nace de ordinario en dicha Parroquia como es grande que en muriendo algún pobre que no tiene con qué enterrarse se levantan algunas personas tales más con celo de avaricia que de caridad y piden limosna para enterrar el pobre y llegan muchos dineros y se quedan con la mayor parte gastan lo que les parece sin dar cuenta a nadie defraudando la limosna de los verdaderos pobres y esto no lo podrán hacer si hay personas diputadas que cuiden de este ministerio y obra de caridad." Archivo Histórico Nacional (hereafter AHN), Consejos, libro 1204, fol. 216ff.

29 “.... entre los pobres enfermos de los que se ocupaba ... soldados, gente que le apiadaban grandemente con sus necesidades y miserias por verlos detenidos en la corte con sus provisiones y despachos muriendo de hambre y sin amparo y favor después de haber defendido a costa de sus miembros y vertiendo su propia sangre la patria, la religión y el rey." Herrera y Maldonado, op. cit., note 21 above, fol. 80v.

${ }^{30}$ César Augusto Palomino 'El régimen hospitalario en Madrid a finales del siglo XVI', Villa de Madrid, 1936, 24: $30-40$.
} 


\section{Teresa Huguet-Termes}

A special group among the "new" hospital institutions were those established for foreigners: San Luis de los Franceses for the French, ${ }^{31}$ San Andrés de los Flamencos for the Flemings, ${ }^{32}$ San Pedro de los Italianos (for Italians), San Antonio de los Portugueses (for the Portuguese), and Nuestra Señora de Montserrat de la Corona de Aragón (for those from the Crown of Aragon) were founded in Madrid in the late sixteenth or early seventeenth century, when the city was becoming more cosmopolitan with the arrival of foreigners attracted by the court. These hospitals were all established to attend the sick of their respective nations and their servants and, like the Hospital de la Corte (later called Nuestra Señora del Buen Suceso owing to the image it housed), were expressly excluded from the consolidation process, and some received royal patronage. ${ }^{33}$

At the end of the sixteenth century, the establishment of institutions as a result of the consolidation process might lead one to think that the hospital and welfare work of certain brotherhoods had lost importance. In fact, they gradually evolved new welfare functions for particular groups among the needy as a consequence of the establishment of the court. In this context, should be mentioned Nuestra Señora de la Soledad—studied in detail by José Luis de los Reyes-which was supported by the queen and the nobility, and which, until its disappearance in 1651, took care of foundlings. The confraternity was governed by "principal persons" and associated individuals: nobles, members of the Royal Councils, and high and middle ranking members of the administration. These brethren determined that a specific charitable function should be adopted. After several attempts, they found their role in looking after foundlings at the Hospital de San José, better known as La Inclusa. ${ }^{34}$

The impact of the court in the sixteenth century and the contribution of the social groups that gradually settled there were of fundamental importance in the main developments within the welfare sector. These may be defined as the specialization and expansion of charitable bodies in accordance with reforming criteria, which moved away from the organization of small hospitals towards a new, increasingly centralized hospital and welfare structure, dependent on royal or municipal administration. Thus, hospitals and welfare in Madrid underwent the greatest transformations in their history. Above all, the period from 1580 onwards witnessed the formation of the hospital structure of the villa y corte (town and court), as Madrid used to be called. Subsequently, the types of hospital became more diverse, with new forms of assistance appearing. However, the seeds of what were to be the main trends that defined the overall lines of charity in seventeenth-century Madrid were already to be found in this period.

\section{Madrid and Reform: Trends towards Hospital Consolidation}

The Madrid chronicler Jerónimo de Quintana wrote that he had seen a letter written by Philip II at El Escorial in March 1566 supporting the idea of a hospital unification project

\footnotetext{
${ }^{31}$ Daniel Alcouffe, 'Contribution à la connaissance des émigrés français de Madrid au XVIIe siècle', Mélanges de la Casa de Velázquez, 1966, 2: 179-97.

${ }^{32}$ Vidal Galache, op. cit., note 11 above.

${ }^{33}$ Lopezosa Aparicio, op. cit., note 10 above.

${ }^{34}$ Reyes Leoz, op. cit., note 8 above, both references.
} 


\section{Madrid Hospitals and Welfare}

(contrary to the wishes of the diocesan council of Toledo). The king stated that the reform was just and convenient and should be put into practice, provided the Pope, who "surely will permit it", gave permission. ${ }^{35}$ Prior to 1566, the number of hospitals in Madrid had increased - thanks to the gold produced by wars and colonization-with the foundation of luxurious institutions such as the Hospital de la Corte exclusively devoted to caring for the personnel of the court. The Hospital de la Pasión for women (1565) had also been founded, as had the hospital of "Convalecientes de Unciones" (before 1566) by the brotherhood of Bernardino de Obregón, as well as the Hospital de la Misericordia (1559). Although the first phase was not completed until 1581, the unification process started in 1566, as Philip wanted. He received two papal briefs in 1566 and 1567 allowing him to undertake the amalgamation of eleven hospitals in Madrid, ${ }^{36}$ and it seems that on 10 November 1581 provision was made to confirm this process. ${ }^{37}$ The subsequent confirmation was issued on 17 February 1587. The General Hospital was put under the protection of a member of the Royal Council, the most powerful political institution of the monarchy, and was located initially at the end of Prado street. ${ }^{38}$ In theory, along with sick paupers, it should have housed vagrants and beggars, but, as will be seen, this was never put into practice. ${ }^{39}$

Although the first reference to the functioning of the new General Hospital dates only to 1581 , the consolidation process was probably rapidly put into practice after 1566 since, as the residence of the court, Madrid was especially susceptible to the dictates of the crown. The city did not "possess an abundance of wealthy confraternities, a large, powerful cathedral chapter, or a recalcitrant bishop, only the vicar of Madrid (presumably appointed by the Archbishop of Toledo in whose diocese Madrid fell), who was treated very much as a crown servant by the Royal Council". Also, in 1566 Madrid had a mere fifteen hospitals. ${ }^{40}$ When the consolidation process was largely completed in 1587, apart from those for foreigners, the city was left with four hospitals: the Hospital de la Corte, a peripatetic institution that accompanied the Castilian court and cared for the courtiers; La Latina, an old, wealthy, private foundation; Antón Martín, a more recent foundation of the followers of John of God, which treated contagious diseases and also formed a part of the General Hospital; and the new General Hospital. ${ }^{41}$

Interestingly, the chronicler Quintana stated in 1629 that the process had been a mistake "as experience has demonstrated", because twelve or twenty sick people could be better treated in a small hospital than two hundred or seven hundred in a larger one, since it was easier to provide relief to a small number. ${ }^{42}$ However, Quintana may not have been an objective spectator. At the time he was writing his book, he was rector of the Hospital de la Latina, one of the few not included in the consolidation process. Not only did he live there, but he also sold his book about the greatness of Madrid at its main entrance. In

\footnotetext{
${ }^{35}$ Varela Hervías (ed.), op. cit., note 17 above, p. 230.

${ }^{36}$ Novísima recopilación de las leyes de España, Madrid, 1805-1829, not. 2, tit. 38, lib. 7.

${ }^{37}$ ARCM, Fondo Diputación, leg. 5083-9, quoted in Charles Davis and John E Varey, Los corrales de comedias y los hospitales de Madrid, 1574-1615. Estudio y documentos, 2 vols, Madrid, Támesis, 1997, vol. 1, p. 139.

${ }^{38}$ Ibid.; Herrera y Maldonado, op. cit., note 21 above, fol. 80 r.

${ }^{39}$ ARCM, Fondo Diputación, leg. 5222/10, fol. 11r.

${ }^{40}$ Martz, op. cit., note 7 above, p. 81, cf.Varela Hervías (ed.), op. cit., note 17 above, pp. 99-100, 445-54.

${ }^{41}$ Herrera y Maldonado, op. cit., note 21 above, fol. 80 r.

${ }^{42}$ Varela Hervías (ed.), note 17 above, p. 231.
} 


\section{Teresa Huguet-Termes}

addition, as noted by Martz, more recent historians than Quintana criticized the Madrid consolidation process on the grounds that the hospitals which treated foreign communitiesthe Italians, the French, the Flemings, the Aragonese-were not included. As she correctly demonstrated, this is a misinterpretation of the aims of the changes and the role of the foreign hospitals. A licence from the crown was necessary before these hospitals could be founded and in 1578, when the Italians sought such a licence, the President of the Royal Council urged that it be granted.

All the council ... resolved that Your Majesty should give them the licence since no difficulties can be found; rather it is an advantage to the court and an alleviation to the hospitals of the court. Since this hospital will travel with the court, it does not come under the law that all hospitals should be fused into one (as the Hospital de la Corte does not). The licence should be given to them with the provision that they do not beg alms in the court. ${ }^{43}$

Furthermore, the historians cited by Martz did not realize that most of these hospitals for foreigners were founded long after the consolidation process had finished.

\section{The General Hospital of Madrid (1581-1598): The Emphasis on Sick Paupers}

From its inception in 1581, the General Hospital of Madrid was administered by Bernardino de Obregón and staffed by the brothers of a society he had founded in 1567 at the Hospital de la Corte, called the Servants of the Poor (Siervos de los Pobres). In 1579, Obregón, a special favourite of Philip II, had sold all his possessions to found the Hospital de Convalecientes in the houses of Santa Ana, subsequently incorporated with the General Hospital. ${ }^{44}$ For many years the General Hospital was funded solely through alms collected by him as "owner and provider of everything", ${ }^{45}$ and from 1589 onwards, the head brother of the Siervos de los Pobres served as the administrator. Over and above this congregation was the Hospitals Board (Junta de los Hospitales), whose members included three members of the Royal Council. Thus, from the beginning, the General Hospital in Madrid and its associated houses were closely supervised by the crown. ${ }^{46}$

The hospitals were financed in a variety of ways. From 1584 they shared in the profits from the performance of plays staged in the city. ${ }^{47}$ Though moralists like the Jesuit Pedro de Guzmán were scandalized by certain aspects of the plays, the money they brought in was of enormous importance to the hospitals. Another source of income came from the excise taxes levied on coal, oil and meat. The hospitals also received a portion of any unused merchandise or money confiscated by the judges for legal infractions. ${ }^{48}$

\footnotetext{
${ }^{43}$ Archivo General de Simancas, Patronato Real, leg. 10, cited in Martz, op. cit., note 7 above, pp. 81-2.

${ }^{44}$ ARCM, Fondo Inclusa, leg. 763/3, fol. $47 \mathrm{v}$.

${ }^{45}$ ARCM, Fondo Inclusa, leg. 763/3, fol. 27r.

${ }^{46}$ ARCM, Fondo Diputación, leg. 5222/10, fols. 13v-16v.

${ }^{47}$ Davis and Varey, op. cit., note 37 above, vol. 1, pp. 13-36.

${ }^{48}$ See Diego de Barrionuevo, Relación de las consignaciones, y efetos que han tenido los hospitales reales, Madrid, Imprenta del Reino, 1657; Gregorio de Aldana y Arellano, La mayor piedad y grandeza de Madrid, en la cura, sustento y regalo que haze a sus pobres enfermos en los Reales Hospitales de esta Corte, General, Passión, Convalecientes y faltos de juicio, Madrid, Imprenta del Reino, 1661; Gregorio de Aldana y Arellano, Los hospitales reales General, Passión de esta Corte con sus convalecencias, y curación de faltos de juicio. Obligaciones, salario
} 


\section{Madrid Hospitals and Welfare}

As already noted, the Madrid hospital consolidation process was not popular with everybody. In fact, in November 1598 the Castilian Cortes, previously supporters of the changes, did an abrupt about-turn and petitioned Philip III to break up the General Hospital complex. ${ }^{49}$ The procuradores (procurators or members of the Cortes) maintained that the hospital was overcrowded, its income poorly administered, and a great portion of its available funds spent on supporting its large staff. The population of Madrid had increased since Philip II had selected it as the residence of the court, and New Castile suffered frequent grain shortages and disease in the last third of the sixteenth century, so the hospitals were bound to be overstretched. These objections were only a preface to the true cause of discontent, the General Hospital's lack of money from charitable benefactors. It was precisely the consolidation and reduction of spiritual obligations which in the procurators' view discouraged benevolent patrons:

When there were many hospitals, persons were moved to leave their fortune for something so holy and necessary, seeing that their spiritual obligations were conserved ... By fusing all the hospitals into one, the spiritual obligations of the founders are obscured, which is the reason why those persons who ought to leave their worldly possessions to hospitals leave them for other pious works that conserve these obligations. ${ }^{50}$

Consolidation was thus very much a crown project. In 1589 the hospital theoretically provided relief for many "sorts" of poor people, with the sick, the injured, convalescents, the incurably sick, and those suffering from contagious diseases treated in Antón Martín being especially prominent. However, the ordinances also refer to beggars, the elderly, the lame and "other disabled individuals who are not able to serve nor to work", as well as transient priests, pilgrims, captive soldiers, pretendientes (aspirants to positions at court), the worthy poor, and "others", who were received at the hospital "because of the consolidation". The ordinances discriminated positively in favour of the first sort: "those who should be given better care, treatment and service, because their needs are greater". ${ }^{51}$ Thus it can be seen that as early as 1589 the royal authority provided care and treatment first and foremost for sick paupers and not indiscriminately for all categories of poor people. The well-being of sick paupers was a cause for complaint against various office-holders. At the beginning of the seventeenth century, the twenty-four deputies of the Hospital de la Pasión

y ración de sus ministros y sirvientes. Su gobierno político y asistencia de los enfermos que se reciben en ellos, Madrid, Imprenta del Reino, 1666; Leonardo Galdiano y Croy, Breve tratado de los hospitales y casas de recogimiento desta corte, Madrid, Imprenta del Reino, 1677.

${ }^{49}$ Varela Hervías, op. cit., note 17 above, pp. 100, 448; Actas de las Cortes de Castilla, Madrid, Establecimiento Tipográfico "Sucesores de Rivadeneyra", 1861-1936, vol. 15, pp. 729-39, vol. 16, pp. 651-3 (both as quoted by Martz, op. cit., note 7 above, pp. 83-4).

50 "Cuando existían muchos hospitales, las personas estaban movidas a dejar sus fortunas a causas tan santas y necesarias, viendo que así preservaban sus obligaciones espirituales. Fusionando todos los hospitales en uno, las obligaciones espirituales de los fundadores quedan oscurecidas, que es la razón por la cual esas personas que deberían dejar sus posesiones terrenales a los hospitales, las dejan a otras obras pías que sí conservan dichas obligaciones." Actas de las Cortes de Castilla, vol. 16, p. 652, cited in Martz, op. cit., note 7 above, p. 84.

51 "Theniendo conservación a que en este Hospital General se recogen muchas suertes de pobres que la una es enfermos, heridos, convalecientes e yncurables, contagiosos, y la otra de mendigos, viejos, manzebos, cojos, y otros pobres ympedidos que no pueden serbir ni travajar. Y que otros son sacerdotes, viandantes, peregrinos y cautibos soldados y pretendientes y otras personas e vergonzantes que todos después de la reducción de los Hospitales ... se reziven en ella. Y los primeros por ser más urgente su necesidad deben ser preferidos y con mayor cuidado remediados así en su curazión, regalo y serbizio.” ARCM, Fondo Diputación, leg. 5222/10, fol. 7v. 


\section{Teresa Huguet-Termes}

complained about the behaviour of the Protector Juan de Tejada because he neglected to appoint commissioners to purchase the necessary provisions for the hospital. Thus when the servants were busy and not able to go to the market to buy goods, the sick poor were unable to enjoy their almendradas (an almond-based drink). ${ }^{52}$

The brothers of the Junta de los Hopitales of the General Hospital asked Philip II to confirm their ordinances in $1589 .{ }^{53}$ At that time Juan de Acuña, a member of the Royal Council, was "Protector of the Hospitals of the Court" (he was given this title in 1587), thus reflecting the fact that the reformation of the hospital was not simply a lay or religious project but a state one. Cardinal Gaspar de Quiroga attended the Junta meetings but, according to the Ordinances, did not play an important role. In 1589 the leading members of the General Hospital, Bernardino de Obregón, and of the House of Antón Martín, Juan Delgado (after the death of John of God), were both hermanos mayores (senior brethren). Junta meetings were held every week. If no member of the Royal Council could attend, at least the vicar of Madrid and the corregidor (chief magistrate) were expected to be there, and as many brothers as possible, but the chief magistrate had no right to take a decision on any difficult matter, a further example of the absolute power of the state. Three times a year, the Junta had the right to visit each hospital and to check on its activities and on the people who worked there. Responsibilities were distributed among the brotherhood of each hospital, and from 1589 onwards, in accordance with the ordinances, "medical men" played a leading role. Each institution was administered by a "senior nursing brother", and a "brother apothecary" was in charge of the apothecary, physicians and barber-surgeons. Two members of the Junta known as semaneros had to be present at the visits of the physicians and surgeons to make sure that the sick received appropriate treatment. ${ }^{54}$ From 1590 onwards, an accountant is mentioned; he was a royal scribe who was responsible for keeping an account of the General Hospital's finances as well as for drawing up the wills of the sick. ${ }^{55}$ All officers were paid salaries, as were the physicians and surgeons. ${ }^{56}$ The Junta presided over everybody from 1587 , nobody could be dismissed nor could any brother or servant be admitted without their agreement. ${ }^{57}$

The sick poor were received during the day or night at whatever time they arrived. Once their personal details had been recorded, they were taken to a special room to be examined by the physicians and surgeons. They were then sent to the "most appropriate" wards, including those in the Antón Martín building. ${ }^{58}$ This information was recorded on a cédula (card) so that the nursing brothers would know which patients had to be accommodated in the beds for which they were responsible. In theory, the sick were provided with clean clothes as soon they had been confessed and had received Holy Communion. All of these conditions were also to be fulfilled at the hospital of Antón Martín as "the latter together with the former are one and the same house". 59 The poor who died were taken out of the

\footnotetext{
${ }^{52}$ AVM, Secretaría, 2-420-9, fol. 1r.

${ }^{53}$ ARCM, Fondo Diputación, leg. 5222/10, fol. 7r.

${ }^{54}$ ARCM, Fondo Diputación, leg. 5222/10, ch. 5.

${ }^{55}$ ARCM, Fondo Inclusa, leg. 763/3, fol. 103r.

${ }^{56}$ ARCM, Fondo Diputación, leg. 5222/10, fol. 3r.

${ }^{57}$ ARCM, Fondo Inclusa, leg. 763/3, fol. 41r.

${ }^{58}$ ARCM, Fondo Inclusa, leg. 763/1, fol. 11v.

${ }^{59}$ ARCM, Fondo Diputación, leg. 5222/10, ch. 1.
} 


\section{Madrid Hospitals and Welfare}

wards if there was no special ward for "good deaths". This was to be done in silence, to avoid making the remaining inmates sad. ${ }^{60}$ The sick were cared for during the whole of their stay, with special attention being given to those in greatest need so that they might quickly recover their health. Once cured, they stayed in the convalescent wards until the physician authorized them to leave the hospital. ${ }^{61}$ By the end of the sixteenth century, the General Hospital seems to have had around 200 beds for men, while the female wards contained about 40 beds, a number which had increased to 200 by $1629 .{ }^{62}$

We do know that the physicians were called to attend the Junta de los Hospitales once a month in order to provide information and give their opinion on illnesses, the hospital's needs, and remedies for the sick, as well as the provision of drugs, and changes to the hospital's apothecary, nursing brothers, barber-surgeons, or nursing apprentices. Despite these important duties, the physicians remained under the supervision of the semaneros and hermano mayor. They were expected to visit the patients twice a day. The same duties were established for surgeons, but they only had to visit their patients once a day. ${ }^{63}$ As early as 1589 an apprentice surgeon was examined in order to qualify as a barber-surgeon; indeed, it was laid down that a person of this level should be present in each ward. Their duties included carrying out phlebotomies, cupping and other activities. In return they received board and lodging but no salary; the medical apprentice, practicante de medicina, who was at the service of the whole hospital to help physicians or stand in for them at night, received similar recompense. ${ }^{64}$

Under the supervision of the enfermero mayor there was an honest and virtuous woman, known as the madre enfermera mayor (matron), whose main function was to supervise the female ward. There was a special ward for women in the General Hospital, as the result of the Hospital de la Pasión being attached to the institution in about 1629. The only men allowed in were the medical practitioners or old men carrying medicines or food from the main larder of the General Hospital. It seems that this ordinance was not completely adhered to and, as Jerónimo de Quintana stated, many sins were committed. These circumstances led to the Hospital de la Pasión returning to its previous premises, ${ }^{65}$ but it remained under the administration of the General Hospital. In about 1638 it moved again to the new hospital building of the General Hospital, which by that date was functioning at the end of Atocha street, a larger structure designed to prevent men and women meeting and thus falling into temptation.

The two apothecary "shops" or pharmacies in the General Hospital and Antón Martín were run by a qualified apothecary, under the superintendence of the brother apothecary, who had no training in pharmacy. From the very beginning, the preparation of drugs was assigned to eminent court apothecaries. For example, in 1589, the royal apothecary José Arigón was entrusted with buying the ingredients for the ointment of Antón Martín

\footnotetext{
${ }^{60}$ ARCM, Fondo Diputación, leg. 5222/10.

${ }^{61}$ ARCM, Fondo Diputación, leg. 5222/10.

${ }^{62}$ ARCM, Fondo Diputación, leg. 5222/10, ch. 17.

${ }^{63}$ ARCM, Fondo Diputación, leg. 5222/10, ch. 8.

${ }^{64}$ ARCM, Fondo Diputación, leg. 5222/10.

${ }^{65}$ Where it had been until 1579 , as is shown by the evidence of a benefactor who gave alms for the sick poor women cared for at that place in 1596. ARCM, Fondo Inclusa, leg. 763/1 fol. 45r.
} 


\section{Teresa Huguet-Termes}

and also with making it. Then Brother Obregón chose an apprentice apothecary to help Arigón. ${ }^{66}$ In 1590, the Hospital de Antón Martín was given 300 reales by the Junta to cover the fees for this ointment. ${ }^{67}$ Antón Martín continued to depend financially on the General Hospital until $1700 .^{68}$

\section{From the Beggars' Shelter Project to the Construction of a New Hospital Building for Sick Paupers}

By 1586 the consolidation of hospitals in Madrid and other Castilian cities was almost complete, and the reformer Miguel de Giginta considered it to be an opportune moment to found shelters for beggars. He therefore approached the Madrid Cortes, and the procurators were sufficiently impressed by the idea to ask the cities that voted in the Cortes for their views. As Martz comments, "In the late 1580s, the king supported a reform that promised to 'purify' Madrid by removing all the undesirable elements of society, with the ultimate result that 'all Spain will be like a school of virtue'." This suggests that in principle the king - as the leading exponent of Catholicism-wanted to reform morality, and that Giginta's ideas may have been influential. ${ }^{69}$ In $1587-88$, Madrid initiated a system to supervise non-residents. Lists of vecinos (inhabitants) for each cuartel or neighbourhood were compiled; any strangers were required to report to an alcalde (judge), and all establishments providing beds for travellers were subject to inspection by the alcaldes. Nevertheless, as will be seen, Spanish monarchs paid little attention to providing relief to the healthy poor.

The transfer of the Madrid General Hospital to the new building in the Calle Atocha in 1603 leads us to consider the acceptance of the beggars' shelter project by the last of the sixteenth-century reformers of poor relief, Cristóbal Pérez de Herrera. These shelters were known as albergues. An albergue provided a place to sleep and a begging licence for those who could not maintain themselves through labour. The Madrid albergue gained support in high places: the president of the Royal Council, Rodrigo Vázquez de Arce; the king's confessor, Diego de Yepes; the tutor of Prince Philip, García de Loaysa; professors of the universities of Salamanca, Valladolid and Alcalá; and the Jesuits, who had previously supported Giginta's project. The crown put pressure on Castilian cities in 1597 to establish albergues. The king arranged for 24,000 ducats and other funds to be provided for the Madrid foundation, and even visited the albergue while it was under construction in Atocha street. ${ }^{70}$ However, although Philip II's son was an advocate of the Madrid albergue in 1596, his interest in it had waned by 1598 when he became king. Herrera lost support at the court of Philip III as the former king's advisers and friends died or were no longer in favour. Although the Cortes honoured Herrera with the title of protector and procuratorgeneral of the albergues, his petitions for financial support went unheeded. Once finished, the albergue was used as a hospital for sick paupers. Then in 1603 it was taken over by the

\footnotetext{
${ }^{66}$ ARCM, Fondo Inclusa, leg. 763/3, fol. 43v.

${ }^{67}$ ARCM, Fondo Inclusa, leg. 763/3, fol. 44v.

${ }^{68}$ ARCM, Fondo Inclusa, leg. 763/3, 14v.

${ }^{69}$ Martz, op. cit., note 7 above, pp. 73-4; British Library, Add. MS 28361, fol. 122, cited in Martz, p. 76.

${ }^{70}$ Martz, op. cit., note 7 above, pp. 88-9; Cavillac, op. cit., note 19 above, pp. XXXVIII-XL, XLIV.
} 


\section{Madrid Hospitals and Welfare}

General Hospital, which had been forced out of its previous location in the carrera de San Jerónimo by the Cardinal Archduke Albert, who had acquired the next-door property. Not wanting the sick poor as his neighbours, he sold their building to the nuns of Saint Catherine. When Herrera died in 1620, his dream died with him. ${ }^{71}$ Only the workhouse for reformed prostitutes, La Galera, which was part of his project, thrived. According to a crown report of 1656, it held seventy women, who spun and wove clothes for patients in other Madrid hospitals. $^{72}$

The Congregation of the Esclavos del Dulcísimo Nombre de María petitioned Queen Mariana, the regent, in 1666 for a hospice to be founded in Madrid. "The fact that the manuscript mentions similar foundations in other 'well-ordered republics' suggests that Castilians were aware of the activities of the French crown, which in 1662 issued an edict ordering that general hospitals be founded in all large urban centres of France." 73 A hospice was established in 1668, but funds were always short. In 1671 the Royal Council gave a succinct résumé of the situation:

The first easily recognizable difficulty is that the establishment of an albergue for all poor beggars seems impossible, or very difficult, in view of the great number who are in the court and those who enter every day because of the fatigue and poverty of the provinces; they would increase still more if they could find a sure meal and shelter. ${ }^{74}$

Nevertheless, funds were forthcoming by 1673 , due to the generosity of private citizens and Madrid's guilds. The hospice was extended to take in another 220 paupers, and moved to Fuencarral street. It was granted royal protection and its name changed to "Dulce Nombre de María y San Fernando, Rey de España", although it was more commonly known as the Hermandad del Hospicio (the Brotherhood of the Hospice). By 1674 the hospice had grown again to include as many as 800 paupers. ${ }^{75}$

\section{Daily Routine at the General Hospital of Madrid: Actors, Activities, and the Counter-Reformation (1603-1677)}

Around 1613 sick paupers were apparently not being treated according to the General Hospital's ordinances of 1589. Antonio Valerio, hermano mayor, was accused of not being present at the visits of physicians and surgeons, not attending lunch with the sick, of being cruel to the poor, and throwing out anyone who disagreed with him. It was also said that he favoured people who exploited the resources of the hospital for their own benefit. ${ }^{76}$ In addition, the appointment of figures such as a royal accountant led to conflict with the brotherhood, who sometimes saw the hospital as its own province. ${ }^{77}$

\footnotetext{
${ }^{71}$ Martz, op. cit., note 7 above, pp. 89-90.

${ }^{72}$ Isabel Barbeito (ed.), Cárceles y mujeres en el siglo XVII. Razón y forma de La Galera. Proceso Inquisitorial de San Plácido, Madrid, Castalia, 1991.

${ }^{73}$ AHN, Consejos, leg. 4168/2; Martz, op. cit., note 7 above, p. 90. For the study of such institutions in France, see Laurence Brockliss and Colin Jones, The medical world of early modern France, Oxford, Clarendon Press, 1997.

${ }^{74}$ British Library, Egerton MSS, 441, fol. 108v, cited in Martz, op. cit., note 7 above, p. 90.

${ }^{75}$ Martz, op. cit., note 7 above, p. 91.

${ }^{76}$ ARCM, Fondo Inclusa, leg. $763 / 3$ fols. $23 \mathrm{v}-24 \mathrm{r}$.

${ }^{77}$ ARCM, Fondo Inclusa, leg. 763/3, fol. 23v.
} 


\section{Teresa Huguet-Termes}

In about 1613, there were one or two physicians, one surgeon, one barber and one bonesetter. ${ }^{78}$ In 1660, the General Hospital paid salaries to four physicians who made two visits a day, one Bachelor of Medicine to replace absent physicians, two surgeons, two surgeons who specialized in phlebotomies, a hernia specialist, a specialist in treatments for urinary disorders, and an eye surgeon. ${ }^{79}$

But around 1613, not only were medically qualified staff in short supply, there was also a lack of nursing staff, as three or four sick paupers per apprentice was considered excessive and "this made tasks difficult". ${ }^{80}$ The nursing staff seems to have shared many duties and the Hospital de la Pasión sought the assistance of an apprentice, who was also a priest, in order to cover as many functions as possible. ${ }^{81}$ To avoid being banned from the institution, a strategy for an incompetent apprentice was that he give alms to the hospital. ${ }^{82}$ By 1676 the situation had improved, with eighty male nursing staff and twenty female at the General Hospital and La Pasión respectively. ${ }^{83}$ The remedies given to the sick (including food and drugs) do not appear to have been of a particularly high quality: in 1613 only raisins, almonds, sugar, medicinas de conserva (preserved medicines), honey, vinegar and oil are mentioned. ${ }^{84}$ Nevertheless, the activity in the apothecary's workroom seems to have increased in the course of the century, and six apothecary apprentices were working with the main apothecary by $1676 .^{85}$

At the beginning of the century the hospital's capacity was insufficient, leading the city council in 1626 to donate some tax revenue to cover the cost of creating new beds. ${ }^{86}$ Gregorio de Aldana, administrator of the hospital, states that in the course of 166015,000 men and women entered the royal hospital for treatment. ${ }^{87}$ In the same year it was announced that three new wards would be built thus increasing the number of beds by about $300 .{ }^{88}$ Since it is known that in 1676 , the General Hospital and La Pasión together had around 562 beds, where, according to Galdiano y Croy, 8,278 sick poor were treated in the course of the year, ${ }^{89}$ we can therefore calculate that at the beginning of the century the General Hospital and La Pasión together had approximately 200 beds. In 1665 there were three large wards at the General Hospital and two more at the Hospital de la Pasion, and when patients arrived at the main entrance they were quickly separated into three categories: ill, tired and "in danger" ${ }^{90}$ In 1660 each ward of the General Hospital was attended by one brother and within the ward ten paupers were cared for by one male nursing apprentice (the women were attended by female nurses). The three "new wards" built to house "more than 300 sick poor", had floors of Toledo tiles, strong iron grilles, doors

\footnotetext{
${ }^{78}$ ARCM, Fondo Inclusa, leg. 763/1, fol. 43r

${ }^{79}$ Aldana y Arellano, La mayor piedad, op, cit., note 48 above, fols. 2, 20r-21r.

${ }^{80}$ ARCM, Fondo Inclusa, leg. 763/2, fol. 5r.

${ }^{81}$ ARCM, Fondo Inclusa, leg. 763/1 fol. 8r.

${ }^{82}$ ARCM, Fondo Inclusa, leg. 763/1 fol. 25v.

${ }^{83}$ Galdiano y Croy, op. cit., note 48 above, pp. 4-5.

${ }^{84}$ ARCM, Fondo Inclusa, leg.763/3.

${ }^{85}$ Galdiano y Croy, op. cit., note 48 above, p. 4 .

${ }^{86}$ AVM, Secretaría, 3-420-16.

${ }^{87}$ Aldana y Arellano, La mayor piedad, op. cit., note 48 above, fol. 2.

${ }^{88}$ Ibid., fol. $5 \mathrm{r}-\mathrm{v}$.

${ }^{89}$ Galdiano y Croy, op. cit., note 48 above, fol. 6 .

${ }^{90}$ Aldana y Arellano, La mayor piedad, op. cit., note 48 above, fol. 2.
} 


\section{Madrid Hospitals and Welfare}

and windows of good wood. Their construction would "prevent beds being placed in the corridors leading to the courtyards, in the church or on the altar steps, or patients even being accommodated in the beds of apprentices or brothers". 91

Archival sources give us a contradictory idea of the quality of care received by the sick. Many patients stated that they were attended with great love and charity. ${ }^{92}$ Others, on the other hand, said that this was not the case. For instance, in about 1613 the matron in charge of the Hospital de la Pasión was accused of not admitting sick paupers, contrary to the instructions of the physicians and priests. She was also denounced for asking the sick to bring their plates and vessels to the hospital so that she could sell them for her own benefit. Those sick paupers who were completely destitute had to wait in the street for someone to give them these things out of charity in order to be received in the hospital. Mother Juana was also charged with being very rude to the sick and even of leaving many at the main door who then died without receiving the sacraments. ${ }^{93}$

From 1609 the pantry contained bread, wheat, wine, candles, oil, spices, and mutton. ${ }^{94}$ The basic diet at both hospitals (to judge by what is recorded for the Hospital de la Pasión) consisted of bread, wine, meat, chicken, eggs, sugar, currants, apples, pears, oil and vinegar. ${ }^{95}$ In 1676, expenditure is recorded on: bread, mutton, wine, eggs, fowl, sponge cakes, oil, sugar, fruit and currants, fat pork, saffron, fish, and sheep's feet, as well as vinegar, lettuce, chickpeas, greens, spices, almonds, salt, and milk. ${ }^{96}$

From at least 1660, one can distinguish between normal remedies and substances in a much more liquid form for those patients who were considered "tired". ${ }^{97}$ The drugs used do not appear to have been very exotic, at least in the period around 1613 if the perplexity caused by the gift of a bezoar stone to the General Hospital by a commissioner of the Council of the Santa Cruzada (Holy Crusade) is borne in mind..$^{98}$ The simplicity of the drugs used is further emphasized by the fact that in 1613 the head of the brotherhood banned a brother from entering the hospital because, as he knew Latin, he argued too much with the brother apothecary about the simple drugs used to make up the medicines. ${ }^{99}$

Although a specific ward for convalescents is not mentioned until 1660, it is quite plausible that convalescents were cared for informally from 1566 in a ward for this purpose. ${ }^{100}$ The mentally ill were housed in a special ward at the General Hospital from $1637 .{ }^{101}$ In about 1661 , ten or twelve mentally ill patients were cared for in

91 ... con las quales se reparava el daño, y descomodidad de que se pongan camas en los corredores, que salen a los patios, en la iglesia, y tarimas de altares ... y aun llegó el caso a términos, que en las camas de platicantes y hermanos se acomodaron', Aldana y Arellano, La mayor piedad, op. cit., note 48 above, fol. 5r-v.

${ }^{92}$ ARCM, Fondo Inclusa, leg. 763/1, fol. 36r.

${ }^{93}$ ARCM, Fondo Inclusa, leg, 763/1, fol. 39v.

${ }^{94}$ ARCM, Fondo Inclusa, 763/3, fol. 37r.

${ }^{95}$ Aldana y Arellano, La mayor piedad, op. cit., note 48 above, fol. 33v.

${ }^{96}$ Galdiano y Croy, op. cit., note 48 above, pp. 7-10.

${ }^{97}$ Aldana y Arellano, La mayor piedad, op. cit., note 48 above, fol. $3 \mathrm{r}$.

${ }^{98}$ ARCM, Fondo Inclusa, leg. 763/2, fol. 22r-23v.

${ }^{99}$ ARCM, Fondo Inclusa, leg. 763/3, fol. $113 \mathrm{r}$.

${ }^{100}$ Aldana y Arellano, La mayor piedad, op. cit., note 48 above, fols. 3v, 6r-v.

${ }^{101}$ Galdiano y Croy, op. cit., note 48 above, fol. 6; Núñez Olarte, op. cit., note 7 above, p. 192. 


\section{Teresa Huguet-Termes}

cages by a brother and two servants. ${ }^{102}$ The same number of staff were looking after the mentally ill in $1676 .^{103}$

In about 1660 , thirty years after it was housed in the same building as the General Hospital, the women at the Hospital de la Pasión were cared for by two physicians, one of whom resided at the hospital while the other was also physician to the royal family, two surgeons, one of whom was also a royal servant, and two phlebotomists. ${ }^{104} \mathrm{~A}$ ward for convalescent women and another for mentally ill women existed by $1660 .{ }^{105} \mathrm{In}$ about 1676 the Hospital de la Pasión paid a salary to two physicians, two surgeons, and two phlebotomists. Among other servants, there were also an apprentice apothecary and twenty nurses. $^{106}$

\section{Towards a Conclusion}

Charity and medicine for a new capital city has been the issue underlying each section of this article. What does this case study of Madrid add to previous studies of welfare in the Catholic world in the early modern period? In 1661, Gregorio de Aldana commented that "the hospital is the bastion of Madrid and the jewel of the monarchy because health is found and all diseases are treated". ${ }^{107}$ However, charity in Madrid, in contrast to other parts of the Catholic world, may have been excessively "afraid" of beggars and vagrancy. Devotional habits that once had sustained welfare projects for the poor and encouraged a spirit of repentance and heroic activity for the faith appear to have been replaced by passive observance. Form dominated content in Spanish piety during the baroque age as clearly as content dominated form in contemporary Protestantism. The suggestion that this was apparent in relation to the care of the sick in Madrid is worth consideration, as is the question why there was so little interest in the relief of potentially healthy workers.

Although much research remains to be carried out, it is possible to draw the following conclusions. The religious element in the Hapsburg capital, as we have seen from María José del Río's studies, is a "form" dominating many "contents"; a "form" that the dynasty did not hesitate to endow with political connotations so as to convert it into an important aspect of ceremony and a demonstration of royal power. ${ }^{108}$ In so far as they were responsible for the spiritual and "temporal" care of the "socially desirable", the Royal Hospitals were able to contribute to the organization of this religious element and to transform themselves into symbols. The famous incident in 1634 when Philip IV, on the way back to his palace from Nuestra Señora de Atocha, with a great retinue in attendance, dismounted from his horse in order to escort a priest who was taking communion to a sick person, should also be remembered. The encounter, according to a contemporary description, was

${ }^{102}$ Aldana y Arellano, La mayor piedad, op. cit., note 48 above, fols. 6v-7v.

${ }^{103}$ Galdiano y Croy, op. cit., note 48 above, fol. 6v.

${ }^{104}$ Aldana y Arellano, La mayor piedad, op. cit., note 48 above, fol. 8v.

${ }^{105}$ Ibid., fol. $11 \mathrm{v}$.

${ }^{106}$ Galdiano y Croy, op. cit., note 48 above, fol. 5 .

107 “"Son la mayor grandeza de la Monarquía de nuestro inclito Felipe IV el Grande, y el mayor blasón de Madrid ... pues a él recurren todas como a centro donde se fragua la salud y donde se curan todos los achaques." Aldana y Arellano, La mayor piedad, op. cit., note 48 above, fol. 1r.

${ }^{108}$ Río Barredo, op. cit., note 14 above, pp. 15, 20. 
exemplary, since this "demonstration of such great religious feeling and piety had taken place before so many and such important witnesses". ${ }^{109}$ Finally, recalling Pullan's work on Venice, we might wonder whether the crown, by monopolizing the care and attention offered to poor patients, assumed the role of a great imaginary "scuola grande" 110 in exchange for the "benefits" of participating in and fulfilling those elements that led to the integration of religious aspects with royal power.

The relief of potential healthy workers seems to have been viewed as uninteresting "content" in the new capital. Two reasons may be suggested. The first is the reaction in about 1666 of the Royal Council regarding the establishment of a hospice for beggars: why found a hospice if the healthy poor were well maintained by the alms given by good people? The second is that the confinement of healthy beggars in closed institutions was associated with Protestant practices at that time. ${ }^{111}$ In that sense, a plausible hypothesis is that it could have been very appropriate to keep the Catholic "form" at least in Madrid, "the core" of the Catholic sphere of the world, by allowing the healthy poor to beg, instead of confining them on the Protestant model, thus giving alms-givers the opportunity to practise charity publicly.

\footnotetext{
${ }^{109}$ Claudio Clemente, El maquiavelismo degollado por la cristiana sabiduría de España y de Austria, Alcalá, Por Antonio Vázquez, 1637, pp. 174-8, as quoted by Río Barredo, op. cit., note 14 above, pp. 184-5.

${ }^{110}$ Fernando Díez Rodríguez has also emphasized the importance of that reciprocity by stating that usually the poor preferred to stay at home instead of going to the hospital, because they perceived the hospital ward as a "totum revolutum". The reason for this was that they were placed near to other poor people whom they felt were not as "respectable" as they themselves. See Fernando Díez Rodríguez, Viles y mecánicos: trabajo y sociedad en la Valencia preindustrial, València, Edicions Alfons el Magnànim, 1990, pp. 112-13.

${ }^{111}$ Many of these issues are discussed in Norbert Finzsch and Robert Jütte (eds), Institutions of confinement: hospitals, asylums and prisons in western Europe and North America, 1500-1950, Cambridge, Cambridge University Press, 1996.
} 